\title{
HEGESZTÉSI PARAMÉTEREK HATÁSA KORRÓZIÓVAL VALÓ SZEMBENI ELLENÁLLÁSRA AUSZTENITES ROZSDAMENTES ACÉLOKNÁL
}

\section{THE EFFECT OF WELDING PARAMETERS BY CORROSION RESISTANCE AUSTENITIC STAINLESS STEEL}

\author{
Kemény Dávid Miklós ${ }^{1}$, Fábián Enikő Réka ${ }^{2}$ \\ Budapesti Müszaki és Gazdaságtudományi Egyetem, Gépészmérnöki Kar, \\ Anyagtudomány és Technológia Tanszék, Cím: 1111, Magyarország, Budapest, \\ Bertalan Lajos utca, 7. Telefon / Fax: +3614632836, \\ ${ }^{1}$ kemenydavid@gmail.com; ${ }^{2}$ fabianr@eik.bme.hu
}

\begin{abstract}
The corrosion resistance of stainless steels depends on a protective, passive film being formed at the steel surface on exposure to the service environment. The use of fusion welding for fabrication leads to local compositional variations within the material, which may significantly alter the stability of the passive layer and hence the corrosion behaviour. In this work were examined the effect of welding parameters (shielding gas, amperage) on corrosion resistance of X6CrNiTi18-10 austenitic stainless steel tubes. The corrosion test was performed according to ASTM G48 standard.
\end{abstract}

Keywords: welding, corrosion, ASTM G48, shielding gas, amperage

\section{Összefoglalás}

A korrózióálló acéloknál a korrózióállóságot az acél felületén keletkező króm-oxid réteg biztosítja. Hegesztéskor az acél homogenitása változik, ami a korrózióállóságot befolyásolja. Kísérleteinknél az X6CrNiTi18-10 típusú korrózióálló ausztenites acélcsöveknél vizsgáltuk a korrózióra való hajlamot különböző hegesztési paraméterek mellett (védőgáz, áramerősség). Eredményeink azt mutatják, hogy a korrózióra való hajlam a nagyobb védőgáz és a kisebb áramerősség esetén kisebb mértékü. A korróziós tesztet ASTM G48 szabvány szerint végeztük.

Kulcsszavak: hegesztés, korrózió, ASTM G48, védőgáz, áramerösség

\section{Bevezetés}

A villamosenergia nélkülözhetetlen a mindennapokban, amelynek elöállítása erőmüvekben történik. Általánosan elmondható, hogy egy energiahordozó hasznosítását követően a kazánokon, gőzfejlesztőkön keresztül történik a hőhordozó közeg energiaátadása melyet gőzképződés kísér és a turbinákat meghajtva a generátoron keresztül villamos áram keletkezik. Az energiaátadást korrózióálló hőátadó csöveken valósítják meg. Ezeknél a termékeknél fontos az alapanyag jó korrózióállósága. Mint ismeretes a korrózióállóság feltétele, hogy az acél felületén alakuljon ki egy stabil, egybefüggő, passzív réteg, aminek feltétele, hogy a $\mathrm{Cr} \geq 12 \%$ és $\mathrm{C} \leq 1,2 \%$. 
A passzivitást az acél felületén keletkező króm-oxid réteg biztosítja, amelyben az alapanyaghoz képest feldúsul a króm. A rozsdamentesség feltétele, hogy az ötvözet szerkezete homogén legyen, sehol ne alakuljon ki krómban szegényebb rész.

A hőátadó csövek a nagy nyomás és a hőmérséklet hatására tönkremehetnek, javításuk hőerőmüveknél lehetséges hegesztéssel. A javítási költségek sokkal kisebbek, mint teljes hőcserélö cseréje. Mivel hegesztéskor a passzív réteg sérülhet, a hegesztéskor a varrat egyes részeinek korróziós ellenállása megváltozik az alapanyagéhoz képest [1], fontos ismernünk, hogy milyen paraméterekkel lehet a hegesztést úgy elvégezni, hogy annak környezete a lehető legjobb korrózióállóságot mutasson.

\section{Vizsgálati anyagok, eljárások}

Kutatásaink során X6CrNiTi18-10 típusú (1.4541 számjelü) ausztenites korrózióálló csövek korrózióra való hajlamát vizsgáltuk különböző paraméterekkel végzett volfrámelektródás védőgázos ívhegesztés (TIG) után. Az X6CrNiTi18-10 típusú acél jellemző összetétele tömegszázalékban: $\mathrm{C} \leq 0,08 \%$; $\mathrm{Cr}=17-19 \% ; \mathrm{Si} \leq 1 \% ; \mathrm{Mn} \leq 2 \% ; \mathrm{Ni}=9-12 \%$; $\mathrm{P} \leq 0,045 \% ; \mathrm{S} \leq 0,015 \% ; \mathrm{Ti} \leq 0,7 \%$. A vizsgálatainkhoz $40 \mathrm{~mm}$ átmérőjü és $2 \mathrm{~mm}$ falvastagságú korrózióálló acélcsövet használtunk. A varratkialakításhoz 316 típusú hozaganyagot alkalmaztunk.

A hegesztési folyamat során az ív a volfrámelektróda és a hegesztendő anyag között alakul ki, melynek során az ív és az ömledék védelmét az argon védőgáz biztosította. A hegesztés során váltakozó áramú kapcsolást alkalmazunk. E kapcsolás esetén a tisztító és felhevítő periódus egymást követi, ezáltal megfelelően mély és közepesen széles ömledék keletkezik, amely során a volfrám terhelhetösége sokkal kisebb mértékü. [2]
Kísérleteinkhez a varratok létrehozásához az áramerősséget változtattuk. Kíváncsiak voltunk, hogy a védögáz mennyisége a korróziós hajlamot hogyan befolyásolja. A mintavételezés paramétereinek összegzését az 1. táblázat foglalja magába a minták betüjelekkel való jelölésével.

1. táblázat. A minták hegesztési paramétereinek összefoglalása

\begin{tabular}{|c|c|c|}
\hline Minta & Védőgáz & Áramerösség \\
\hline $\mathbf{I}$ & $61 / \mathrm{min}$ & $50 \mathrm{~A}$ \\
\hline $\mathbf{J}$ & $61 / \mathrm{min}$ & $55 \mathrm{~A}$ \\
\hline $\mathbf{G}$ & $61 / \mathrm{min}$ & $60 \mathrm{~A}$ \\
\hline $\mathbf{L}$ & $101 / \mathrm{min}$ & $50 \mathrm{~A}$ \\
\hline $\mathbf{H}$ & $101 / \mathrm{min}$ & $55 \mathrm{~A}$ \\
\hline $\mathbf{K}$ & $101 / \mathrm{min}$ & $60 \mathrm{~A}$ \\
\hline
\end{tabular}

A hegesztést követően a varratok és azok környezetének ferrittartalmát Fischer FMP30 típusú ferritszkóppal határoztuk meg. Ahogy azt a 2. táblázatban láthatjuk 10 liter/perc védőgáz alkalmazásával a varrat ferrit tartalma kevesebb, mint a kevesebb gázzal való gyökvédelemkor, de melegrepedés így sem keletkezett a varratfémben (1. ábra).

2. táblázat. A minták varratainak és környezetüknek ferrit tartalma százalékban

\begin{tabular}{|c|c|c|c|c|c|}
\hline \multirow{2}{*}{ Minta } & \multicolumn{5}{|c|}{ Ferrit tartalom (\%) } \\
\cline { 2 - 6 } & Alapa. & $\begin{array}{c}\text { Höhat. } \\
\text { öv }\end{array}$ & Varrat & $\begin{array}{c}\text { Höhat. } \\
\text { öv }\end{array}$ & Alapa. \\
\hline I & 0,77 & 3,1 & 3,2 & 1,6 & 0,47 \\
\hline J & 0,46 & 1,3 & 3,6 & 2,8 & 0,42 \\
\hline G & 0,26 & 2,6 & 3 & 2,7 & 0,37 \\
\hline L & 0,3 & 1,9 & 2,3 & 2,8 & 0,34 \\
\hline H & 0,29 & 2,1 & 3,1 & 2,7 & 0,27 \\
\hline K & 0,43 & 1,4 & 2,2 & 1,6 & 0,34 \\
\hline
\end{tabular}



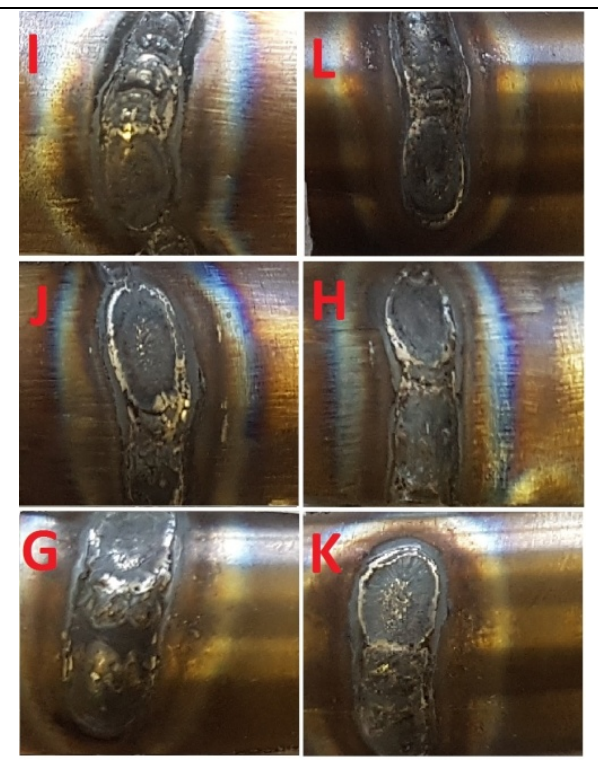

1. ábra. Sztereomikroszkópos felvételek a minták felületéröl hegesztés után

A különböző paraméterekkel hegesztett mintákat korróziós tesztnek vetettük alá az ASTM G48 szabvány szerint. Korróziós közegként vas(III)-klorid $6 \%$ oldatot használtunk. A minták tömegveszteségét 24 óra elteltével vizsgáltuk. A mérésekhez APX - 200 típusú, 0,1 mg mérési pontosságú, precíziós mérleget használtunk. A vizsgált minták tömegmérési adatait a 3 . táblázatban láthatjuk.

3. táblázat. A minták kezdeti és 24 óra elteltével mért tömegei, illetve a tömegveszteség évre vonatkoztatva

\begin{tabular}{|c|c|c|c|}
\hline & \multicolumn{2}{|c|}{ Tömeg (gramm) } & $\begin{array}{c}\text { Tömegveszteség } \\
{[\mathbf{g} / \text { év/cm }}\end{array}$ \\
\hline Minta & 0. óra & 24. óra & 24. óra \\
\hline I & 18,8983 & 18,5292 & 5,73 \\
\hline J & 16,6738 & 16,3142 & 5,94 \\
\hline G & 14,9801 & 14,6136 & 7,35 \\
\hline L & 22,5622 & 22,1625 & 5,11 \\
\hline H & 16,0077 & 15,6329 & 6,47 \\
\hline K & 17,6556 & 17,2563 & 6,51 \\
\hline
\end{tabular}

\section{Eredmények értékelése}

Majdnem minden esetben megállapítható volt, hogy a nagyobb mennyiségü védőgáz, kisebb tömegveszteséggel járt. Bár a szabvány a lyukkorrózió jelenségét tömegveszteség szerint értékeli, a korróziós lyukak habitusából adódóan nem tökéletes ez az értékelés. Figyelembe kell venni hol jelennek meg a lyukak, milyen mennyiségben fordulnak elő.

Megfigyeltük, hogy a lyukkorrózió megjelenése (2.ábra) főleg a hőhatás övezetben játszódott le, ahogy azt a sztereomikroszkópos felvételek mutatják.

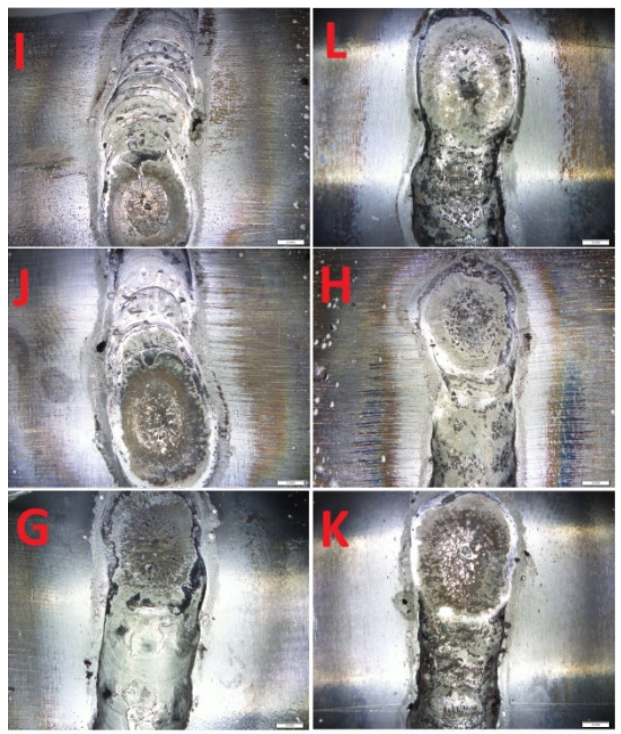

2. ábra. A minták felülete a korróziós tesztet követöen

A korróziós károsodások elemzése érdekében a varratok felületén lévő lyukak számát is figyelembe véve elöször az áramerősségek szerint ábrázoltuk a kapott értékeket, majd a védőgáz mennyisége alapján (3.-7. ábra).

Ahogy azt a 3.-5. ábrákon bemutatott oszlopdiagramok alapján is megállapítható a tömegveszteség az áramerősség növelé- 
sével nő, míg az egységnyi felületre eső lyukak száma csökken.

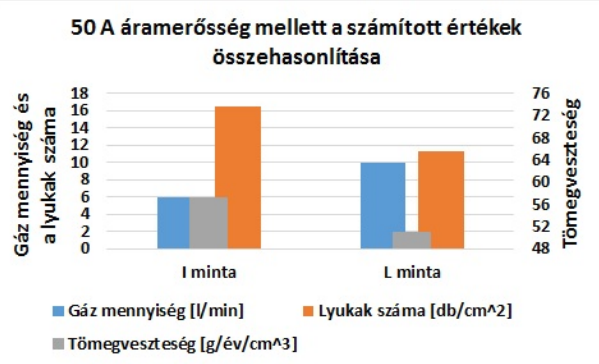

3. ábra. A 6 és 10 liter/perc védőgáz mennyiség esetén tömegveszteség és a lyukak száma 50 amper áramerősség esetén

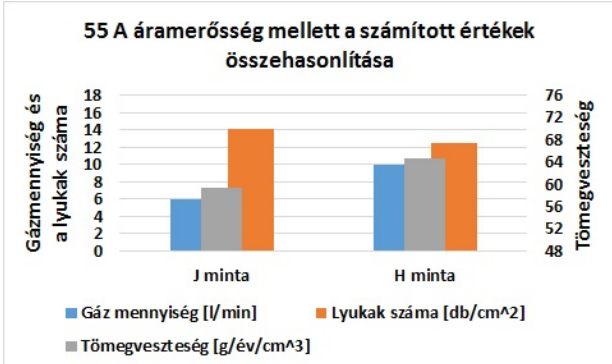

4. ábra. $A 6$ és 10 liter/perc védögáz mennyiség esetén tömegveszteség és a lyukak száma 55 amper áramerösség esetén

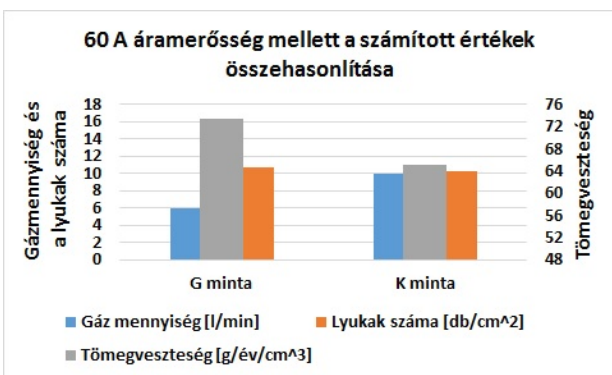

5. ábra. A 6 és 10 liter/perc védögáz mennyiség esetén tömegveszteség és a lyukak száma 6amper áramerösség esetén

A 6.-7. ábra alapján megállapítottuk, hogy 6 liter/perc védőgáz esetén az áramerősség növekedésével a tömegveszteség csökkent, és a 10 liter/perc védőgáz mennyiség esetében az 50 amper áramerősség mellett volt a legkisebb a tömegveszteség, lyukak számában nincs jelentős eltérés.

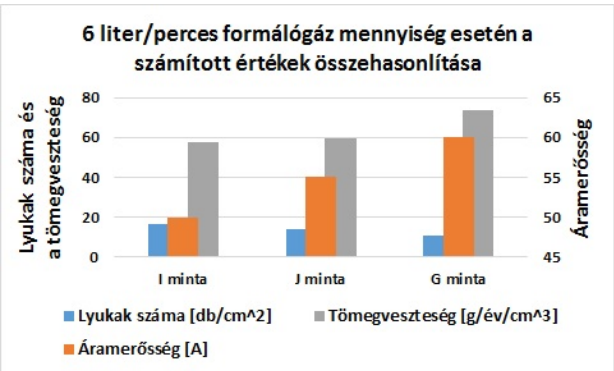

6. ábra. $A z 50,55$ és 60 amper áramerősség esetén a tömegveszteség és a lyukak száma 6 liter/perc védögáz esetén

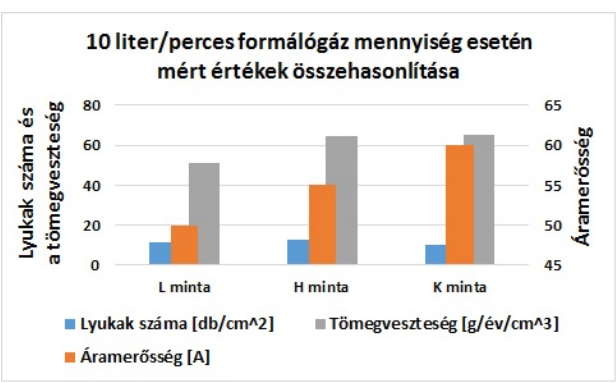

7. ábra. $A z 50,55$ és 60 amper áramerősség esetén a tömegveszteség és a lyukak száma 10 liter/perc védögáz esetén

\section{Következtetések}

A vizsgálatok azt mutatták, hogy a legkisebb tömegveszteség és kis lyukszám is társul 10 liter/perc védőgáz mennyiség és 50 amper áramerősség mellett alakult ki.

\section{Szakirodalmi hivatkozások}

[1] M Dadfar, M.H. Fathi, F. Karimzadeh, M.R. Dadfar, A. Saatchi: Effect of TIG welding on corrosion behavior of $316 \mathrm{~L}$ stainless steel, Materials Letters 61 (2007) 2343-2346.

[2]Baránszky-Jób Imre: Hegesztési kézikönyv. Müszaki Könyvkiadó, Budapest, 1985, 364366. 